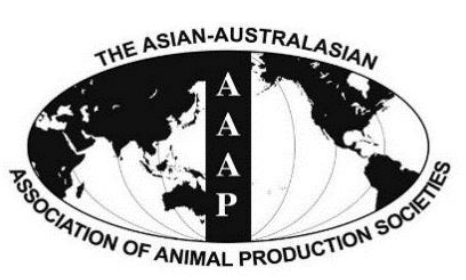

Open Access

Asian Australas. J. Anim. Sci.

Vol. 29, No. 6 : 865-871 June 2016

http://dx.doi.org/10.5713/ajas.15.1050

\author{
www.ajas.info
}

pISSN 1011-2367 elSSN 1976-5517

\title{
Effects of Replacing Pork Back Fat with Canola and Flaxseed Oils on Physicochemical Properties of Emulsion Sausages from Spent Layer Meat
}

\author{
Ki Ho Baek, Dicky Tri Utama, Seung Gyu Lee, Byoung Ki An'1, and Sung Ki Lee* \\ Animal Products and Food Science Program, Division of Animal Applied Science, College of Animal Life Sciences, \\ Kangwon National University, Chuncheon 24341, Korea
}

\begin{abstract}
The objective of this study was to investigate the effects of canola and flaxseed oils on the physicochemical properties and sensory quality of emulsion-type sausage made from spent layer meat. Three types of sausage were manufactured with different fat sources: $20 \%$ pork back fat (CON), $20 \%$ canola oil (CA) and $20 \%$ flaxseed oil (FL). The pH value of the CA was significantly higher than the others $(\mathrm{p}<0.05)$. The highest water holding capacity was also presented for CA; in other words, CA demonstrated a significantly lower water loss value among the treatments $(\mathrm{p}<0.05)$. CA had the highest lightness value $(\mathrm{p}<0.05)$. However, FL showed the highest yellowness value $(\mathrm{p}<0.05)$ because of its own high-density yellow color. The texture profile of the treatments manufactured with vegetable oils showed higher values than for the CON $(p<0.05)$; furthermore, CA had the highest texture profile values $(\mathrm{p}<0.05)$ among the treatments. The replacement of pork back fat with canola and flaxseed oils in sausages significantly increased the omega-3 fatty acid content ( $p<0.05$ ) over 15 to 86 times, respectively. All emulsion sausages containing vegetable oil exhibited significantly lower values for saturated fatty acid content and the omega- 6 to omega-3 ratios compared to $\mathrm{CON}(\mathrm{p}<0.05)$. The results show that using canola or flaxseed oils as a pork fat replacer has a high potential to produce healthier products, and notably, the use of canola oil produced characteristics of great emulsion stability and sensory quality. (Key Words: Spent Layer Meat, Fat Replacer, Canola Oil, Flaxseed Oil, Emulsion Stability, Fatty Acid Profile)
\end{abstract}

\section{INTRODUCTION}

Nowadays, consumers are gradually interested in foods that not just support nutritional needs, also concern health benefits (Kim et al., 2010). People are concerning about their bad or irregular dietary habits, especially depend too much on meat consumption. According to Mathijs (2015), the consumption of meat appears two different aspects: positive and negative effects for human health in developing and developed countries, respectively. Indeed, high quality products are regarded as healthy products that contain low amounts of fat, additive agents, salt content (Kruk et al., 2014). Omar et al. (2009) noted that people demand foods containing a variety of nutrients for a lifetime of health.

\footnotetext{
* Corresponding Author: Sung Ki Lee. Tel: +82-33-250-8646, Fax: +82-33-250-5574, E-mail: skilee@ kangwon.ac.kr

1 Department of Animal Science and Technology, Konkuk University, Seoul 05029, Korea.

Submitted Dec. 22, 2015; Revised Feb. 6, 2016; Accepted Mar. 8, 2016
}

Accordingly, modern society requires food companies to produce healthier products. For developing healthier products, the most important thing is to manufacture foods that reduce the unhealthy aspects and improve the healthy aspects which mainly depend on the type of raw materials and the fat sources.

The consumption of spent layer as partial meat resources has increased (Kim, 2014). At the same time, many researchers are putting efforts to optimize the use of spent layer because of their depreciation. According to $\mathrm{Wu}$ and Wang (2012), the disposal of spent layer can lead to making some economic and environmental concerns in the poultry industry. However, these resources, despite being less tender than broiler meat, can be a good raw material (Hollender et al., 1987). Moreover, by using spent layer at the end of a laying cycle as a raw material for meat products with other ingredients of higher nutritional value, it is possible to provide economic benefits to the poultry industry (Souza et al., 2011).

Copyright $\odot 2016$ by Asian-Australasian Journal of Animal Sciences This is an open-access article distributed under the terms of the Creative Commons Attribution Non-Commercial License (http://creativecommons.org/licenses/by-nc/3.0/) which permits unrestricted non-commercial use, distribution, and reproduction in any medium, provided the original work is properly cited. 
Generally, emulsion-type meat products are manufactured from beef, pork, or chicken with pork back fat (Jo et al., 2015), and these conventional meat products contains up to $30 \%$ fat (Choi et al., 2010b). According to Youssef and Barbut (2009), the fats and oils play important roles, especially regarding the functional and sensory quality, for many food products. However, many researchers have reported that high fat intake can cause cardiovascular disease and obesity because of the production of low density lipoprotein-cholesterol (Jo et al., 2015). The reduction of animal fat through the use of non-meat materials, for example dietary fiber and isolated soy protein, could produce healthier meat products (Choi et al., 2010b). Vegetable oils have also been used as replacements of animal fat in low-fat meat products (Ambrosiadis et al., 1996; Muguerza et al., 2001).

Canola and flaxseed oils contain a high amount of omega-3 fatty acids (Bozan and Temelli, 2008; Moon et al., 2011; Suksombat et al., 2013). González-Esquerra and Leeson (2001) noted that omega-3 fatty acids have the possibility for reducing rates of various diseases, such as cardiovascular disease and diabetes. In addition, according to the WHO (2003), to reduce coronary heart disease, linoleic acid is the best replacement of saturated fatty acids. These bioactive compounds can also give some assistance to body growth (Omar et al., 2009). In medical and scientific communities, mono-unsaturated fats acquired from dietary sources have received attention for their potential health benefits (Rhee et al., 1988). However, because of their high polyunsaturated fatty acids (PUFA) values, vegetable oils have the possibility to quickly reduce the product stabilities (Choo et al., 2007). Xiong and Jiang (2015) noted that providing oxidative stability with the use of vegetable oils with high PUFA values would be an important challenge to researchers.

The objective of this study was to investigate the effects of canola and flaxseed oils as a pork fat replacer in emulsion sausages made from spent layer meats to find ways to optimize the health ratings of spent layer products. Furthermore, these products could be a valuable food resource for people who do not consume pork materials for various reasons (i.e., religion, preference, etc.).

\section{MATERIALS AND METHODS}

\section{Materials}

Twenty spent layers (Hy-line; 70 weeks old) were purchased from JUNG-WOO-FOOD Agricultural Co., Ltd. (Korea) and approximately $20 \mathrm{~kg}$ of pork back fats were purchased from a local meat shop. These materials were then transferred to polyethylene-vacuum-pack bags and vacuumpackaged using a vacuum sealer (SBV-400TS, SB Tech, Gimpo, Korea). They were stored at $-24^{\circ} \mathrm{C}$ until needed for product manufacture. Fresh canola oil was purchased from a local market and flaxseed oil was purchased from SSAM-GFNB Organic Product Co., Ltd. (Seoul, Korea).

\section{Meat batters and emulsion sausages preparation}

All subcutaneous fat and visible connective tissue were removed from the chicken breast. Approximately $20 \mathrm{~kg}$ of the spent layer breast meat and pork back fat were separately ground using a meat chopper (M-12S, HANKOOK FUJEE MACHINERY Co., Ltd., Hwaseong, Korea) with a 6-mm plate. Three meat batters were prepared for each treatment with the formulations given in Table 1 . The first emulsion sausage was a control $(\mathrm{CON})$ prepared with $20 \%$ pork back fat and the other two emulsion sausages were prepared with each $20 \%$ canola and flaxseed oils as the fat replacer. At three-step emulsification process was performed to produce high-quality emulsion sausages. In the first step, the chicken breast was emulsified for $6 \mathrm{~min}$ in a silent cutter (OMF-500, Ohmichi Co., Ltd., Maebashi, Japan $)$ together with ice $\left(0^{\circ} \mathrm{C}\right)$, $1.5 \%$ salt, $0.3 \%$ curing salt $(93.1 \%$ salt, $5.9 \%$ sodium nitrite, and $1.0 \%$ sodium carbonate), and $0.3 \%$ sodium tripolyphosphate. Second, $0.5 \%$ bologna seasoning, $0.5 \%$ beef powder, $0.5 \%$ sugar, $0.1 \%$ black pepper, $0.5 \%$ chopped onion, and iced water $\left(2^{\circ} \mathrm{C}\right)$ were added and emulsified for $4 \mathrm{~min}$. Then, $4 \%$ potato starch, $1 \%$ isolated soy protein, $0.05 \%$ smoke solution and ice water $\left(2^{\circ} \mathrm{C}\right)$ were finally added and

Table 1. The formulations of emulsion sausages made from spent layer meat using canola and flaxseed oils

\begin{tabular}{|c|c|c|c|}
\hline \multirow{2}{*}{ Ingredients (\%) } & \multicolumn{3}{|c|}{ Treatments $^{1}$} \\
\hline & $\mathrm{CON}$ & $\mathrm{CA}$ & FL \\
\hline Chicken breast & 60 & 60 & 60 \\
\hline Pork back fat & 20 & 0 & 0 \\
\hline Canola oil & 0 & 20 & 0 \\
\hline Flaxseed oil & 0 & 0 & 20 \\
\hline Ice & 20 & 20 & 20 \\
\hline Total & 100 & 100 & 100 \\
\hline Salt & 1.50 & 1.50 & 1.50 \\
\hline Curing salt ${ }^{2}$ & 0.30 & 0.30 & 0.30 \\
\hline Tri-polyphosphate ${ }^{3}$ & 0.30 & 0.30 & 0.30 \\
\hline Bologna seasoning & 0.50 & 0.50 & 0.50 \\
\hline Beef powder & 0.50 & 0.50 & 0.50 \\
\hline Sugar & 0.50 & 0.50 & 0.50 \\
\hline Black pepper & 0.10 & 0.10 & 0.10 \\
\hline Chopped onion & 0.50 & 0.50 & 0.50 \\
\hline Potato starch & 4.00 & 4.00 & 4.00 \\
\hline Smoke solution & 0.05 & 0.05 & 0.05 \\
\hline ISP & 1.00 & 1.00 & 1.00 \\
\hline
\end{tabular}

ISP, isolated soy protein.

${ }^{1} \mathrm{CON}$, spent layer sausage with $20 \%$ pork back fat; CA, spent layer sausage with $20 \%$ canola oil; FL, spent layer sausage with $20 \%$ flaxseed oil.

${ }^{2} 93.1 \%$ salt, $5.9 \%$ sodium nitrite, and $1.0 \%$ sodium carbonate.

${ }^{3} 40 \%$ sodium polyphosphate, $30 \%$ sodium pyrophosphate dehydrate, and $30 \%$ sodium pyrophosphate. 
mixed for 4 min. For the meat batter experiment, the meat batter samples were stored at $4^{\circ} \mathrm{C}$ in the dark and under vacuum conditions up until the analyses for color, $\mathrm{pH}$, emulsion stability, and water holding capacity (WHC). Another set of meat batter samples was filled into collagen casings (\#260, Nippi Collagen Ind., Tokyo, Japan; 26-mm diameter) using a sausage filler (DK-9, Friedr. Dick GmbH \& Co. KG, Deizisau, Germany). They were then heated to $80^{\circ} \mathrm{C}$ for $30 \mathrm{~min}$ in a water bath (BW-20G, Jeio Tech Co., Daejon, Korea). The emulsion sausage products were cooled with cold running water for $30 \mathrm{~min}$ and dried at $4^{\circ} \mathrm{C}$ for $1 \mathrm{~h}$. After drying, the products were stored at $4^{\circ} \mathrm{C}$ in the dark and under vacuum conditions until quality analyses.

\section{Instrumental surface color and $\mathbf{p H}$ evaluation}

The instrumental surface color of each meat batter was determined by using chroma-meter (CR-400, Konica Minolta Sensing Inc., Osaka, Japan) measuring lightness (Commission Internationale de l'Eclairage [CIE] L*-value), redness (CIE $\mathrm{a}^{*}$-value) and yellowness (CIE $\mathrm{b}^{*}$-value); illuminate $\mathrm{C}$ was calibrated with a white standard plate ( $\mathrm{Y}=$ 93.6, $\mathrm{X}=0.3134, \mathrm{y}=0.3194)$. Chroma $\left(\mathrm{C}^{*}\right)$ was measured using data processing equipment (DP-400, Konica Minolta Sensing Inc., Japan). The color measurement was performed 5 times on each batter sample. To measure the $\mathrm{pH}$, a homogenizer (PH-91, SMT Co., Chiba, Japan) was used to homogenize $5 \mathrm{~g}$ of each batter in $50 \mathrm{~mL}$ of distilled water for $1 \mathrm{~min}$ at $10,000 \mathrm{rpm}$. The $\mathrm{pH}$ values were recorded in triplicate using a $\mathrm{pH}$ meter (SevenEasy $\mathrm{pH}$, Mettler-Toledo $\mathrm{GmbH}$, Schwerzenbach, Switzerland).

\section{Emulsion stability and water holding capacity}

The emulsion stability and WHC were measured in triplicate using the Choi et al. (2007) method and Laakkonen et al. (1970) method with slight modifications. First, a sieve ( $4 \times 4 \mathrm{~cm}, 19 \mathrm{mesh})$ was put in the middle of a specially formed centrifuge tube. Approximately $10 \mathrm{~g}$ of meat batter samples were then placed on the sieve, and covered with aluminum foil. Samples were cooked at $75^{\circ} \mathrm{C}$ for $30 \mathrm{~min}$ in a water bath and cooled in a $2^{\circ} \mathrm{C} \pm 1^{\circ} \mathrm{C}$ chilling room for $30 \mathrm{~min}$. Each water and fat layer was measured using tube gradation and then calculated as follows:

$$
\begin{aligned}
& \text { Water loss }(\%)=\frac{\text { The water layer }(\mathrm{mL})}{\text { Weight of raw meat batter }(\mathrm{g})} \times 100 \\
& \text { Fat loss }(\%)=\frac{\text { The fat layer }(\mathrm{mL})}{\text { Weight of raw meat batter }(\mathrm{g})} \times 100
\end{aligned}
$$

Samples were then centrifuged at $1,000 \mathrm{rpm}$ for $10 \mathrm{~min}$ at $4{ }^{\circ} \mathrm{C}$. Aluminum foil and meat samples were then discarded, and each tube was determined by weight change after $24 \mathrm{~h}$ at $100^{\circ} \mathrm{C}$. The WHC was measured by calculating the percentage of the total moisture and the water loss as follows:

$$
\text { WHC }(\%)=\frac{\text { Total moisture }(\%)-\text { water loss }(\%)}{\text { Total moisture }(\%)} \times 100
$$

\section{Warner-Bratzler shear force and texture profile analysis}

The Warner-Bratzler shear force (WBSF) and the texture profile analysis (TPA) were performed at room temperature using a texture analyzer (TA-XT2i, Stable Micro Systems Ltd., Goldalming, Surrey, England). Ten cubed $(1 \times 1 \times 1 \mathrm{~cm}$; width $\times$ length $\times$ height) samples taken from the central portion of each emulsion sausage were equilibrated to room temperature. The shear force (WBSF) values were determined using a $3 \mathrm{~mm}$ Warner-Bratzler shear blade. The texture analysis (TPA) conditions were as follows: pre-test speed, $2.0 \mathrm{~mm} / \mathrm{s}$; post-test speed, $5.0 \mathrm{~mm} / \mathrm{s}$; maximum load, $2 \mathrm{~kg}$; head speed, $2.0 \mathrm{~mm} / \mathrm{s}$; distance, $8.0 \mathrm{~mm}$; and force, $5 \mathrm{~g}$. Values for the shear force $(\mathrm{kg})$, hardness $(\mathrm{kg})$, springiness $(\mathrm{cm})$, cohesiveness, gumminess $(\mathrm{kg})$, chewiness $(\mathrm{kg})$, and resilience $(\mathrm{mm})$ were determined.

\section{Sensory evaluation}

Spent layer sausages were cooked to $80^{\circ} \mathrm{C}$ for $30 \mathrm{~min}$ in a water bath (BW-20G, Jeio Tech Co., Korea) and then cooled to $4^{\circ} \mathrm{C}$. The sensory evaluation was performed in triplicate on each sample coded with a randomly selected digit number. The 10 semi-panelists were asked to evaluate the color, texture, taste, aroma, and overall acceptance on a 9-point hedonic scale: 1-most unpleasant, very unpleasant, moderately unpleasant, slightly unpleasant, neither pleasant nor unpleasant, slightly pleasant, moderately pleasant, 9most pleasant. The panelists were required to cleanse their palates with water between samples.

\section{Fatty acid composition}

The fatty acid composition was determined in triplicate using a gas chromatograph (YL6500, YL Instrument, Anyang, Korea). The lipid fraction of the sausages was extracted according to Folch et al. (1957) and methylated as described by AOAC (1995). Fatty acid methyl esters were separated using an Omega wax-320 fused silica capillary column ( $30 \mathrm{~m} \times 0.32 \mathrm{~mm}$ i.d., $0.25 \mu \mathrm{m}$ film thickness; Supelco, Inc., Bellefonte, PA, USA). The fatty acid peaks were identified by comparing with the retention times and peak areas of fatty acids standard mixtures (Supelco 47015-U, USA).

\section{Statistical analysis}

The complete data set was subjected to one-way analysis of variance using R-version 3.1.2 with the "Agricolae" library (The R-foundation for Statistical Computing, Vienna, Austria). The statistical significance of the differences between means from different treatments was determined by 
Duncan's multiple range test $(\mathrm{p}<0.05)$.

\section{RESULTS AND DISCUSSION}

\section{pH and color evaluation}

The results of the $\mathrm{pH}$ values and colors of the meat batters are presented in Table 2. The $\mathrm{pH}$ of the canola oil sausage (CA) was higher than for the other treatments $(\mathrm{p}<0.05)$. Similar results, presenting higher $\mathrm{pH}$ values in meat batters formulated with vegetable oils than in batters with pork back fat were reported by Choi et al. (2009) and Choi et al. (2010a). However, there were no significant differences between control and flaxseed oil sausage (FL).

The lightness (CIE L*) of the CA was significantly higher than that of other treatments, and the CON had the highest redness $\left(\mathrm{CIE} \mathrm{a}^{*}\right)$ value $(\mathrm{p}<0.05)$. This result agrees with Koo et al. (2009) who indicated that the lightness of emulsions before cooking was higher in vegetable oil treatments than those in tallow. Similar results were also reported by Youssef and Barbut (2009) in which the lightness of meat emulsions prepared with canola oil were higher than those prepared with the beef fat treatments, and the results for redness exhibited a reversed pattern. They also indicated a relationship and difference between smaller oil globules and larger fat globules with reflection as an explanation for these results. However, FL, even though it was manufactured with vegetable oil, showed the lowest lightness value $(\mathrm{p}<0.05)$. This was probably a result of its own high-density yellow color, which could also be confirmed from the highest chroma (CIE C*) value of FL. This result agrees with Park et al. (2005), who obtained the lowest lightness from low-fat hamburger patties produced with olive oil. FL also had the highest yellowness (CIE $b^{*}$ ) value compared to other treatments $(\mathrm{p}<0.05)$. Many researchers have reported that the yellowness values increased when the meat batters were manufactured with vegetable oils as animal fat replacement (Park et al., 2005; Koo et al., 2009). For this reason, FL was likely to be affected by consumer preferences.

Table 2. The $\mathrm{pH}$ and color of meat batters made from spent layer meat using canola and flaxseed oils

\begin{tabular}{lcccc}
\hline \multirow{2}{*}{ Traits } & \multicolumn{3}{c}{ Treatments $^{1}$} & \multirow{2}{*}{ SEM } \\
\cline { 2 - 4 } & CON & CA & FL & \\
\hline $\mathrm{pH}$ & $6.13^{\mathrm{b}}$ & $6.22^{\mathrm{a}}$ & $6.13^{\mathrm{b}}$ & 0.01 \\
$\mathrm{CIE} \mathrm{L}^{*}$ & $82.9^{\mathrm{b}}$ & $83.7^{\mathrm{a}}$ & $77.9^{\mathrm{c}}$ & 0.70 \\
$\mathrm{CIE} \mathrm{a}^{*}$ & $1.22^{\mathrm{a}}$ & $1.05^{\mathrm{b}}$ & $-0.82^{\mathrm{c}}$ & 0.25 \\
$\mathrm{CIE} \mathrm{b}^{*}$ & $10.7^{\mathrm{c}}$ & $11.5^{\mathrm{b}}$ & $25.2^{\mathrm{a}}$ & 1.78 \\
$\mathrm{CIE} \mathrm{C}^{*}$ & $10.8^{\mathrm{c}}$ & $11.5^{\mathrm{b}}$ & $25.2^{\mathrm{a}}$ & 1.78 \\
\hline
\end{tabular}

SEM, standard error of the means; CIE, Commission Internationale de l'Eclairage.

${ }^{1} \mathrm{CON}$, spent layer sausage with $20 \%$ pork back fat; CA, spent layer sausage with $20 \%$ canola oil; FL, spent layer sausage with $20 \%$ flaxseed oil.

a-c Means within each row with different superscripts are significantly different $(\mathrm{p}<0.05)$.

\section{Water holding capacity and emulsion stability}

The WHC and emulsion stability of the meat batters were affected by the emulsified formulation, which designed using different fat sources (Table 3 ). The addition of canola oil as a pork back fat replacer in emulsion sausages significantly increased the WHC more than the traditional sausage results $(p<0.05)$. In addition, the CA showed the lowest water loss among the treatments $(\mathrm{p}<0.05)$. Xiong and Jiang (2015) noted that the interfacial protein membrane and the size of the emulsion droplet played important roles in forming the stability of the emulsions. Canola oil could form emulsions more tightly than beef fat because of its smaller fat globules, which provided extensive surface space to protein (Youssef and Barbut, 2009). They reported that meat batters manufactured with canola oil, at the protein levels below $13 \%$, had significantly lower water losses than meat batters manufactured with beef fat. Many researchers have also found that meat emulsions prepared with vegetable oils, especially with canola oil, had equivalent or higher WHC than those of emulsions prepared with animal fat (Álvarez et al., 2011; Youssef and Barbut, 2011). Moreover, according to (Park et al., 2005; Koo et al., 2009), patties prepared with vegetable oils had decreased cooking loss. Although the batter temperature increased to $20^{\circ} \mathrm{C}$, the emulsion stability of the meat products designed with vegetable oil was stable (Ambrosiadis et al., 1996). However, there were no significant difference in fat losses between $\mathrm{CON}$ and CA. On the other hand, water loss and fat loss were significantly higher in FL $(p<0.05)$. In other words, FL had the most unstable emulsion stability among the samples. This is probably related to different inner structures such as the size of fat globules or different susceptibility to processing temperatures.

\section{Shear force and texture profile analysis}

The effects of canola and flaxseed oils on the textural properties of the emulsion sausage are also given in Table 4 . The shear force of CA was significantly higher than that of CON and FL $(p<0.05)$. Except for springiness, the highest

Table 3. A comparison of the emulsion stabilities and water holding capacities of meat batters made from spent layer meat using canola and flaxseed oils

\begin{tabular}{lcccc}
\hline \multirow{2}{*}{ Traits } & \multicolumn{3}{c}{ Treatments $^{1}$} & \multirow{2}{*}{ SEM } \\
\cline { 2 - 4 } & CON & CA & FL & \\
\hline Water holding capacity (\%) & $83.1^{\mathrm{b}}$ & $92.3^{\mathrm{a}}$ & $74.9^{\mathrm{c}}$ & 1.06 \\
Emulsion stability & & & & \\
$\quad$ Water loss (mL/g) & $6.53^{\mathrm{b}}$ & $1.93^{\mathrm{c}}$ & $13.5^{\mathrm{a}}$ & 1.71 \\
Fat loss (mL/g) & $1.96^{\mathrm{b}}$ & $1.93^{\mathrm{b}}$ & $4.82^{\mathrm{a}}$ & 0.48 \\
\hline
\end{tabular}

SEM, standard error of the means.

${ }^{1} \mathrm{CON}$, spent layer sausage with $20 \%$ pork back fat; CA, spent layer sausage with $20 \%$ canola oil; FL, spent layer sausage with $20 \%$ flaxseed oil.

${ }^{a-c}$ Means within each row with different superscripts are significantly different $(\mathrm{p}<0.05)$. 
hardness, cohesiveness, gumminess, chewiness, and resilience values were observed in the CA treatment $(\mathrm{p}<0.05)$. Youssef and Barbut (2011) noticed that adding canola oil as a beef fat replacement significantly increased the hardness, cohesiveness, chewiness, and gumminess. According to Choi et al. (2009), the meat emulsions prepared with various vegetable oils and rice bran fiber as the pork back fat replacer had higher hardness values than those of meat batters containing pork back fat. However, in this experiment, the texture profile of FL showed similar results to that of CON, which added pork back fat. These results were probably due to the lower WHC and emulsion stability of the FL treatment, especially compared to those of CA. These results showed that the use of canola oil could result in a stable emulsion and better texture because of its high WHC.

\section{Sensory evaluation}

Table 5 shows the sensory evaluation results. The color score of CA was higher than for other treatments $(\mathrm{p}<0.05)$. This probably resulted from its higher lightness value (Table 2), which created a synergic effect between the chicken breast (i.e., the white muscle) and the clean liquid canola oil. The texture of CA was also higher than for CON and FL because of its higher textural properties (Table 4). However, there was no significant difference in taste among the samples. The lowest flavor and overall acceptance values were found in emulsion sausages prepared with flaxseed oil. These might be due to the specific strong flavor and yellow color of flaxseed oil which could be divided into likes or dislikes according to individual preference.

\section{Fatty acid profile}

Table 6 shows the fatty acid profile of emulsion sausages made from spent layer with fat replacements. The highest saturated fatty acids (SFA) were observed in CON $(\mathrm{p}<0.05)$, which was manufactured with pork back fat. This content mainly consists of palmitic acid (C16:0) and stearic acid

Table 4. A comparison of the texture properties of emulsion sausages from spent layer meat using canola and flaxseed oils

\begin{tabular}{lcccc}
\hline \multirow{2}{*}{ Traits } & \multicolumn{3}{c}{ Treatments $^{1}$} & \multirow{2}{*}{ SEM } \\
\cline { 2 - 4 } & CON & CA & FL & \\
\hline Shear force (kg) & $0.57^{\mathrm{b}}$ & $1.24^{\mathrm{a}}$ & $0.60^{\mathrm{b}}$ & 0.07 \\
Hardness $(\mathrm{kg})$ & $3.65^{\mathrm{b}}$ & $11.2^{\mathrm{a}}$ & $4.01^{\mathrm{b}}$ & 0.74 \\
Springiness $(\mathrm{cm})$ & $0.85^{\mathrm{b}}$ & $0.83^{\mathrm{b}}$ & $0.92^{\mathrm{a}}$ & 0.01 \\
Cohesiveness & $0.24^{\mathrm{c}}$ & $0.45^{\mathrm{a}}$ & $0.29^{\mathrm{b}}$ & 0.02 \\
Gumminess $(\mathrm{kg})$ & $0.87^{\mathrm{b}}$ & $5.01^{\mathrm{a}}$ & $1.15^{\mathrm{b}}$ & 0.40 \\
Chewiness $(\mathrm{kg})$ & $0.75^{\mathrm{c}}$ & $4.15^{\mathrm{a}}$ & $1.06^{\mathrm{b}}$ & 0.32 \\
Resilience $(\mathrm{mm})$ & $0.11^{\mathrm{b}}$ & $0.26^{\mathrm{a}}$ & $0.11^{\mathrm{b}}$ & 0.02 \\
\hline
\end{tabular}

SEM, standard error of the means.

${ }^{1} \mathrm{CON}$, spent layer sausage with $20 \%$ pork back fat; CA, spent layer sausage with $20 \%$ canola oil; FL, spent layer sausage with $20 \%$ flaxseed oil.

${ }^{\mathrm{a}-\mathrm{c}}$ Means within each row with different superscripts are significantly different $(\mathrm{p}<0.05)$.
Table 5. A comparison of the sensory properties of emulsion sausages from spent layer meat using canola and flaxseed oils

\begin{tabular}{lcccc}
\hline \multirow{2}{*}{ Traits $^{1}$} & \multicolumn{3}{c}{ Treatments $^{2}$} & \multirow{2}{*}{ SEM } \\
\cline { 2 - 4 } & CON & CA & FL & \\
\hline Color & $6.60^{\mathrm{a}}$ & $6.10^{\mathrm{a}}$ & $5.40^{\mathrm{b}}$ & 0.28 \\
Texture & $6.00^{\mathrm{b}}$ & $7.20^{\mathrm{a}}$ & $6.50^{\mathrm{b}}$ & 0.22 \\
Taste & 6.10 & 6.80 & 6.20 & 0.21 \\
Flavor & $6.40^{\mathrm{a}}$ & $6.20^{\mathrm{a}}$ & $5.50^{\mathrm{b}}$ & 0.24 \\
Overall acceptance & $6.20^{\mathrm{a}}$ & $6.60^{\mathrm{a}}$ & $5.65^{\mathrm{b}}$ & 0.20 \\
\hline
\end{tabular}

SEM, standard error of the means.

${ }^{1}$ Each trait was evaluated on a 9-point hedonic scale: 1-most unpleasant, very unpleasant, moderately unpleasant, slightly unpleasant, neither pleasant nor unpleasant, slightly pleasant, moderately pleasant, 9-most pleasant.

${ }^{2} \mathrm{CON}$, spent layer sausage with $20 \%$ pork back fat; CA, spent layer sausage with $20 \%$ canola oil; FL, spent layer sausage with $20 \%$ flaxseed oil.

${ }^{a-b}$ Means within each row with different superscripts are significantly different $(\mathrm{p}<0.05)$.

(C18:0). The PUFA content of FL was significantly higher than for the other treatments $(\mathrm{p}<0.05)$, and most of the PUFA were made up of alpha-linolenic acid (C18:3n-3). According to Bozan and Temelli (2008), flaxseed oil retained over $80 \%$ unsaturated fatty acids, which mostly consist of linolenic acid. CA also contained higher PUFA than the conventional one $(\mathrm{p}<0.05)$. In this case, however, PUFA were mostly made up with linoleic acid (C18:2n-6). The highest oleic acid (18n:1n-9) was observed in CA $(p<0.05)$, which was

Table 6. A comparison of the fatty acid profiles of emulsion sausages from spent layer meat using canola and flaxseed oils

\begin{tabular}{lcccc}
\hline \multirow{2}{*}{ Fatty acid } & \multicolumn{3}{c}{ Treatments $^{1}$} & \multirow{2}{*}{ SEM } \\
\cline { 2 - 4 } & CON & CA & FL & \\
\hline C14:0 & $1.39^{\mathrm{a}}$ & $0.00^{\mathrm{b}}$ & $0.01^{\mathrm{b}}$ & 0.23 \\
C16:1n-7 & $34.0^{\mathrm{a}}$ & $5.19^{\mathrm{b}}$ & $6.12^{\mathrm{b}}$ & 4.75 \\
C18:0 & $1.75^{\mathrm{a}}$ & $0.02^{\mathrm{b}}$ & $0.01^{\mathrm{b}}$ & 0.29 \\
C18:1n-9 & $26.1^{\mathrm{a}}$ & $0.80^{\mathrm{b}}$ & $4.93^{\mathrm{b}}$ & 3.98 \\
C18:2n-6 & $27.5^{\mathrm{b}}$ & $66.3^{\mathrm{a}}$ & $30.4^{\mathrm{b}}$ & 6.31 \\
C18:3n-6 & $8.49^{\mathrm{c}}$ & $20.2^{\mathrm{a}}$ & $16.1^{\mathrm{b}}$ & 1.73 \\
C18:3n-3 & $0.08^{\mathrm{a}}$ & $0.01^{\mathrm{b}}$ & $0.01^{\mathrm{b}}$ & 0.01 \\
C20:4n-6 & $0.46^{\mathrm{c}}$ & $7.15^{\mathrm{b}}$ & $42.3^{\mathrm{a}}$ & 6.50 \\
C22:4n-6 & $0.08^{\mathrm{a}}$ & $0.01^{\mathrm{b}}$ & $0.05^{\mathrm{c}}$ & 0.01 \\
C22:6n-3 & $0.11^{\mathrm{a}}$ & $0.06^{\mathrm{b}}$ & $0.04^{\mathrm{c}}$ & 0.01 \\
SFA & $0.01^{\mathrm{b}}$ & $0.18^{\mathrm{a}}$ & $0.03^{\mathrm{b}}$ & 0.03 \\
MUFA & $61.5^{\mathrm{a}}$ & $5.99^{\mathrm{b}}$ & $11.1^{\mathrm{b}}$ & 8.94 \\
PUFA & $29.2^{\mathrm{b}}$ & $66.4^{\mathrm{a}}$ & $30.4^{\mathrm{a}}$ & 6.16 \\
PUFA/SFA & $9.25^{\mathrm{c}}$ & $27.6^{\mathrm{b}}$ & $58.5^{\mathrm{a}}$ & 7.19 \\
n-3 & $0.15^{\mathrm{b}}$ & $4.80^{\mathrm{a}}$ & $5.30^{\mathrm{a}}$ & 0.84 \\
n-6 & $0.49^{\mathrm{c}}$ & $7.35^{\mathrm{b}}$ & $42.4^{\mathrm{a}}$ & 6.49 \\
n-6/n-3 & $8.75^{\mathrm{c}}$ & $20.3^{\mathrm{a}}$ & $16.1^{\mathrm{b}}$ & 1.70 \\
\hline
\end{tabular}

SEM, standard error of the means; SFA, saturated fatty acids; MUFA, monounsaturated fatty acids; PUFA, polyunsaturated fatty acids.

${ }^{1} \mathrm{CON}$, spent layer sausage with $20 \%$ pork back fat; CA, spent layer sausage with $20 \%$ canola oil; FL, spent layer sausage with $20 \%$ flaxseed oil.

${ }^{a-c}$ Means within each row with different superscripts are significantly different $(\mathrm{p}<0.05)$. 
prepared with canola oil. Many researchers also found that canola oil has over 50\% oleic acid (Moon et al., 2011; Jung, et al., 2013). Emulsion sausages manufactured with canola and flaxseed oils had PUFA/SFA ratio over 4 . These values were 4 to 5 times higher than for CON. A similar trend was observed by Souza et al. (2011), who manufactured mortadella sausages with spent layer meat and soybean oil and 4 to 5 times higher PUFA/SFA ratio than traditional sausages manufactured with beef and pork fat. The ratios of the omega- 6 to omega-3 fatty acids were significantly $(\mathrm{p}<0.05)$ higher in CON than those of in CA and FL approximately 6 to 45 times, respectively. The ideal ratio of omega- 6 to omega-3 was approximately 1 , and this lower ratio has potential to prevent various diseases (Simopoulos, 2006). Current people gradually consume omega-6 fatty acids, approximately 12 to 30 times higher than omega-3 fatty acids, in their diets (Choo et al., 2007; Park et al., 2014). As a result, CA and FL have the possibility to enhance omega-3 fatty acid contents for health benefits.

\section{CONCLUSION}

Using canola oil as animal fat replacer in manufacturing emulsion sausages not only shows a high potential for emulsion stability derived from its own remarkable WHC, but also appears a stable and tight texture have led to appear highest texture score in sensory evaluations. Moreover, the use of canola oil also showed a high sensory evaluation scores for color, taste, flavor, and overall acceptance, which equivalent to conventional one. Furthermore, the addition of canola oil could help to form ideal ratios of PUFA to SFA and omega- 6 to omega-3 fatty acids.

\section{CONFLICT OF INTEREST}

We certify that there is no conflict of interest with any financial organization regarding the material discussed in the manuscript.

\section{ACKNOWLEDGMENTS}

This research was supported by Export Promotion Technology Development Program, Ministry of Agriculture, Food and Rural affairs, Republic of Korea.

\section{REFERENCES}

Álvarez, D., R. M. Delles, Y. L. Xiong, M. Castillo, F. A. Payne, and J. Laencina. 2011. Influence of canola-olive oils, rice bran and walnut on functionality and emulsion stability of frankfurters. LWT - Food Sci. Technol. 44:1435-1442.

Ambrosiadis, J., K. P. Vareltzis, and S. A. Georgakis. 1996. Physical, chemical and sensory characteristics of cooked meat emulsion style products containing vegetable oils. Int. J. Food Sci.
Technol. 31:189-194.

AOAC. 1995. Official Methods of Analysis. 13th edn. Association of Official Analytical Chemists, Washington, DC, USA.

Bozan, B., and F. Temelli. 2008. Chemical composition and oxidative stability of flax, safflower and poppy seed and seed oils. Bioresour. Technol. 99:6354-6359.

Choo, W. S., J. Birch, and J. P. Dufour. 2007. Physicochemical and quality characteristics of cold-pressed flaxseed oils. J. Food Compost. Anal. 20:202-211.

Choi, Y. S., J. H. Choi, D. J. Han, H. Y. Kim, M. A. Lee, H. W. Kim, J. Y. Jeong, and C. J. Kim. 2009. Characteristics of low-fat meat emulsion systems with pork fat replaced by vegetable oils and rice bran fiber. Meat Sci. 82:266-271.

Choi, Y. S., J. H. Choi, D. J. Han, H. Y. Kim, M. A. Lee, H. W. Kim, J. Y. Jeong, H. J. Chung, and C. J. Kim. 2010a. Effects of replacing pork back fat with vegetable oils and rice bran fiber on quality of reduced-fat frankfurters. Meat Sci. 84:557-563.

Choi, Y. S., J. H. Choi, D. J. Han, H. Y. Kim, M. A. Lee, H. W. Kim, J. W. Lee, H. J. Chung, and C. J. Kim. 2010b. Optimization of replacing pork back fat with grape seed oil and rice bran fiber for reduced-fat meat emulsion systems. Meat Sci. 84:212-218.

Choi, Y. S., M. A. Lee, J. Y. Jeong, J. H. Choi, D. J. Han, H. Y. Kim, E. S. Lee, and C. J. Kim. 2007. Effects of wheat fiber on the quality of meat batter. Korean J. Food Sci. An. 27:22-28.

Folch, J. M., M. Lee, and G. H. Sloan. 1957. A simple method for the isolation and purification of total lipids from animal tissues. J. Biol. Chem. 226:497-514.

González-Esquerra, R. and S. Leeson. 2001. Alternatives for enrichment of eggs and chicken meat with omega-3 fatty acids. Can. J. Anim. Sci. 81:295-305.

Hollender, R., J. H. Macneil, and M. G. Mast. 1987. Effect of fragmentation method and formulation on the quality of patties made from restructured spent layer meat. J. Food Sci. 52:290293.

Jo, Y. J., Y. J. Kwon, S. G. Min, and M. J. Choi. 2015. Changes in quality characteristics of pork patties containing multilayered fish oil emulsion during refrigerated storage. Korean J. Food Sci. An. 35:71-79.

Jung, S. T., D. H. Shin, and Y. S. Kim. 2013. Changes in fatty acid compositions of various edible oils with frying times and food materials. J. Agric. Life Sci. 44:25-31.

Kim, H. Y., E. S. Lee, J. Y. Jeong, J. H. Choi, Y. S. Choi, D. J. Han, M. A. Lee, S. Y. Kim, and C. J. Kim. 2010. Effect of bamboo salt on the physicochemical properties of meat emulsion systems. Meat Sci. 86:960-965.

Kim, Y. J. 2014. The study on the quality of sausage manufactured with different mixture ratios of spent laying hen and pork meat. Korean J. Poult. Sci. 41:271-277.

Koo, B. K., J. M. Kim, I. J. La, J. H. Choi, Y. S. Choi, D. J. Han, H. Y. Kim, K. I. An, and C. J. Kim. 2009. Effects of replacing tallow with canola, olive, corn, and sunflower oils on the quality properties of hamburger patties. Korean J. Food Sci. An. 29:466-474.

Kruk, Z. A., H. J. Kim, Y. J. Kim, D. L. Rutley, S. Jung, S. K. Lee, and C. Jo. 2014. Combined effects of high pressure processing and addition of soy sauce and olive oil on safety and quality characteristics of chicken breast meat. Asian Australas. J. Anim. Sci. 27:256-265.

Laakkonen. E., G. H. Wellington, and J. W. Sherbon. 1970. Low- 
temperature, long- time heating of bovine muscle. I. Changes in tenderness, water-binding capacity, $\mathrm{pH}$ and amount of water soluble components. J. Food Sci. 35:175-177.

Mathijs, E. 2015. Exploring future patterns of meat consumption. Meat Sci. 109:112-116.

Moon, J. H., J. H. Lee, J. A. Shin, S. T. Hong, and K. T. Lee. 2011. Optimization of lipase-catalyzed production of structured lipids from canola oil containing similar composition of triacylglycerols to cocoa butter. J. Korean Soc. Food Sci. Nutr. 40:1430-1437.

Muguerza, E., O. Gimeno, D. Ansorena, J. G. Bloukas, and I. Astiasaran. 2001. Effect of replacing pork back fat with preemulsified olive oil on lipid fraction and sensory quality of chorizo de pamplona-a traditional spanish fermented sausage. Meat Sci. 59:251-258.

Omar, K. A., L. Shan, X. Zou, Z. Song, and X. Wang. 2009. Effects of two emulsifiers on yield and storage of flaxseed oil powder by response surface methodology. Pakistan J. Nutr. 8:1316-1324.

Park, J. C., J. Y. Jeong, E. S. Lee, J. H. Choi, Y. S. Choi, L. H. Yu, H. D. Paik, and C. J. Kim. 2005. Effects of replaced plant oils on the quality properties in low-fat hamburger patties. Korean J. Food Sci. Technol. 37:412-417.

Park, S. O., B. S. Park, I. S. Yuh, J. Hwangbo, and H. T. Bang. 2014. Effect of hanwoo diets containing linseed on plasma cholesterol levels of humans to beef consumption and change in n-6/n-3 fatty acid of loin fat. J. Korean Oil Chem. Soc. 31:265-276.

Rhee, K. S., Y. A. Ziprin, G. Ordonez, and C. E. Bohac. 1988. Fatty acid profiles of the total lipids and lipid oxidation in pork muscles as affected by canola oil in the animal diet and muscle location. Meat Sci. 23:201-210.
Simopoulos, A. P. 2006. Evolutionary aspects of diet, the omega6/omega-3 ratio and genetic variation: Nutritional implications for chronic diseases. Biomed. Pharmacother. 60:502-507.

Souza, K. M. R., R. B. Araujo, A. L. Santos, C. E. C. Rodrigues, D. E. Faria, and M. A. Trindade. 2011. Adding value to the meat of spent laying hens manufacturing sausage with a healthy appeal. Braz. J. Poult. Sci. 13:57-63.

Suksombat, W., C. Meeprom, and R. Mirattanaphrai. 2013. Milk production, milk composition, live weight change and milk fatty acid composition in lactating dairy cows in response to whole linseed supplementation. Asian Australas. J. Anim. Sci. 26:1111-1118.

WHO (World Health Organization). 2003. Diet, nutrition and the prevention of chronic diseases: report of a joint WHO/FAO expert consultation, Geneva, 28 January - 1 February 2002. WHO technical report series; 916, p. 82. http://www.who.int/nutrition/publications/obesity/WHO_TRS_ 916/en/

$\mathrm{Wu}, \mathrm{J}$. and C. Wang. 2012. Preparation and characterization of adhesive from spent hen proteins. Int. J. Adhes. Adhes. 36:8-14.

Xiong, Y. L. and J. Jiang. 2015. Role of interfacial protein membrane in oxidative stability of vegetable oil substitution emulsions applicable to nutritionally modified sausage. Meat Sci. 109:56-65

Youssef, M. K. and S. Barbut. 2009. Effects of protein level and fat/oil on emulsion stability, texture, microstructure and color of meat batters. Meat Sci. 82:228-233.

Youssef, M. K. and S. Barbut. 2011. Fat reduction in comminuted meat products-effects of beef fat, regular and pre-emulsified canola oil. Meat Sci. 87:356-360. 